\title{
EFEKTIFITAS PEMBERIAN SUPLEMEN SERBUK KUNYIT (Currcuma longa L.) TERHADAP JUMLAH BAKAL TELUR (HIERARKI FOLIKEL) PUYUH JEPANG (Coturnix-coturnix japonica $\mathrm{L}$ )
}

\section{Effect of Tumeric Powder Supplementation (Currcuma longa \\ L.) on Total Follicles of Japanese Quail (Coturnix-coturnix japonica $\mathrm{L}$ )}

\section{Sukarman Hadi Jaya Putra}

Program Studi Pendidikan Biologi, Fakultas Keguruan dan Ilmu-ilmu Pendidikan, Universitas Nusa Nipa, Maumere, Indonesia.

email: sukarmanputra@yahoo.com

\begin{abstract}
The purpose of this research was to study the effect of turmeric powder supplementation prior to sexual maturity of Japanese quail's egg. Fortyfive of female quils were assigned into completely randomized design with 3 treatments (P0: without tumeric powder or control, P1: level of turmeric powder $54 \mathrm{mg} /$ quail/day, P2: level of turmeric powder 108 $\mathrm{mg}$ /quail/day) and each treatments used 3 quils with 5 replications respectively. The treatments were administrated every day for 30 days started at the age of 14 days. Parameters measured were number of follicles hierarchy. Statistical analysis used ANOVA followed by Duncan's test. The result showed that administrated turmeric powder suplementation at level $108 \mathrm{mg} /$ quail/day had significantly increase the number of Japanese quail follicles hierarchy prior to sexual maturity.
\end{abstract}

Keywords: Japanese quail, tumeric supplementation, follicles hierarchy.

\section{PENDAHULUAN}

Kebutuhan gizi masyarakat Indonesia mengalami peningkatan. Hardinsyah (2010), menyatakan, bahwa protein hewani merupakan faktor utama yang dapat menentukan tingkat kesejahteraan masyarakat. Presentase distribusi energi pada pola konsumsi di Indonesia adalah 9-14\% energi protein, $24-36 \%$ 
energi lemak, dan 54-63\% energi karbohidrat. Hal tersebut belum sesuai dengan yang distribusi energi yang diharapkan, yaitu 5-15\% energi protein, 25-55\% energi lemak, dan 40-60\% karbohidrat. Rata-rata konsumsi kalori penduduk Indonesia tahun 2011 sebesar 1.952,01 kkal, sedangkan tahun 2012 menjadi 1.852,64 kkal, turun sebesar 99,37 kkal (Respati dkk., 2013).

Puyuh Jepang (Coturnix coturnix japonica L.) menjadi salah satu sektor peternakan yang efisien dalam menyediakan nutrisi, baik berasal dari telur atau daging (Handarini dkk., 2008). Keuntungan beternak puyuh Jepang adalah umur enam minggu puyuh Jepang sudah berproduksi, tidak membutuhkan modal yang besar, mudah pemeliharaannya, dapat diusahakan pada lahan yang terbatas, dan siklus reproduksi yang singkat (Listiyowati dan Roospitasari, 2007).

Telur puyuh Jepang memiliki kadar protein $13,1 \%$ dan lemak 11,1\%, lebih baik dibandingkan telur unggas lainnya yaitu telur ayam ras dan itik. Kadar kolesterol yang tinggi pada darah puyuh Jepang yaitu $700 \mathrm{mg} / \mathrm{dl}$ dapat mengakibatkan peningkatan kadar kolesterol pada daging dan kuning telur puyuh Jepang (Rahmat dan Wiradimadja, 2011). Kolesterol yang tinggi juga ditemukan pada beberapa kuning telur unggas lainnya, seperti kuning telur ayam ras petelur (layer) $732 \mathrm{mg} / \mathrm{dl}$ dan kuning telur ayam kampung atau buras (bukan ras) $715 \mathrm{mg} / \mathrm{dl}$ (Saidin, 2000).

Hierarki folikel puyuh Jepang adalah sekumpulan oosit yang mengalami perkembangan menjadi telur. Hierarki folikel diselubungi oleh vitelogenin yang disintesis di hati dan terdistribusi ke hierarki folikel lewat darah. Kandungan fitoestrogen yang tinggi dapat membantu aktivitas estrogenik pada hewan (Ravindran et al., 2007). Fitoestrogen dapat terikat pada reseptor estrogen.

Vitolegenin pada unggas terdiri dari dua polipeptida yang berisi lipovitelin dan fosvitin. Lipovitelin adalah lipofosfoprotein, $20 \%$ teridiri dari lipid yang terfosforilasi dan $80 \%$ terdiri dari protein. Fosvitin adalah protein pada kuning telur yang disintesis di hati dan diinduksikan oleh hormon estrogen (Yamashita et al., 2011). Hormon estrogen merupakan hormon steroid reproduksi yang mempunyai struktur kimia berintikan steroid. Hormon ini disintesis di dalam sel-sel teka dan sel-sel ovarium. Salah satu 
prekursornya adalah kolesterol dan trigliserida yang dibentuk melalui proses enzimatik. LH dalam sel teka berfungsi meningkatkan aktivitas enzim pembelah rantai sisi kolesterol melalui pengaktifan ATP menjadi cAMP, selanjutnya terbentuk androstenedion. Androstenedion akan berfusi menuju sel granulose, kemudian melakukan aromatisasi membentuk estron dan estradiol $17 \beta$ (Levi et al., 2009).

Kolesterol sangat dibutuhkan oleh tubuh sebagai komponen struktural dan fungsional sel. Kolesterol berfungsi sebagai bahan untuk sintesis hormon steroid, unsur garam empedu, dan prekursor sintesis kuning telur (vitelogenin). Vitelogenin disintesis di hati yang dikemas dalam bentuk VLDL (Very Low Density Lipoprotein), kemudian didistribusikan ke dalam ovarium dan diakumulasikan dalam folikel sebagai kuning telur (Salvante et al., 2007). Lipid dalam telur dan daging puyuh juga cukup tinggi. Lipid dalam sel tubuh berasal dari pakan bersama dengan protein dan karbohidrat. Lipid di dalam sel dikemas dalam bentuk trigliserida (Peter, 2009).

Beberapa jenis bahan herbal yang pernah dijadikan sebagai bahan penelitian dalam menurunkan kadar kolesterol, yaitu bawang putih (El-Sayyad et al., 2010), temulawak (Puastuti, 2001), dan kunyit (Saraswati et al., 2013a). Temulawak dan kunyit mengandung senyawa kurkumin yang dapat berperan sebagai hepatoprotektor (Kohli et al., 2005). Kadar kurkumin pada kunyit adalah 8.6\% lebih tinggi dibanding kadar kurkumin pada temulawak yaitu 2.33\% (Agustina, 2006). Serbuk kunyit merupakan salah satu suplemen yang mempengaruhi kadar lipid. Pemberian suplemen serbuk kunyit dengan dosis 108 mg/ekor/hari dapat menurunkan kadar trigliserida daging, serum dan hati puyuh Jepang (Putra et al., 2015). Kurkumin dapat meningkatkan aktivitas lipoprotein lipase sehingga dapat menurunkan kadar trigliserida dalam darah (Chattopadhyay et al., 2004). Lipid yang berupa kolesterol juga mengalami penurunan setelah pemberian serbuk kunyit, karena kurkumin mampu memacu sintesis reseptor LDL (Emadi et al., 2007).

Pemberian suplemen serbuk kunyit pada pakan puyuh Jepang sebesar $108 \mathrm{mg}$ /ekor/hari sebelum masak kelamin mampu meningkatkan metabolisme lipid berupa kolesterol (putra dkk, 
2016) dan trigliserida (Putra et al., 2015), pendistribusian ke berbagai organ melalui enterohepatik resirkulasi, folikel ovarium (Saraswati et al., 2013b), mengurangi timbunan lemak pada abdominal dan lemak subkutan (putra dkk, 2015), menurunkan kadar kolesterol pada daging dan kuning telur (Putra dkk., 2016). Kurkumin juga dapat meningkatkan metabolisme protein dan kalsium pada puyuh Jepang sehingga dapat memperbaiki produktivitas dan kualitas telur puyuh Jepang (Saraswati et al., 2013b). Penurunan kadar kolesterol serta trigliserida pada darah dikarenakan adanya pendistribusian kolesterol dan trigliserida ke jaringan lain dan hierarki folikel.

Berdasarkan latar belakang di atas, maka diperlukan penelitian untuk menganalisis peningkatan kuantitas dan diameter hierarki folikel puyuh Jepang setelah pemberian suplemen serbuk kunyit sebelum masak kelamin.

\section{METODE PENELITIAN}

\section{a. Waktu dan Tempat Penelitian}

Penelitian ini dimulai dari bulan April sampai bulan Agustus 2014. Pemeliharaan hewan uji dilakukan di Laboratorium Biologi Struktur dan Fungsi Hewan Jurusan Biologi Fakultas Sains dan Matematika Universitas Diponogoro. Pengukuran jumlah hierarki follikel puyuh Jepang dilakukan di tempat yang sama.

\section{b. Bahan dan Alat}

Bahan yang digunakan adalah puyuh Jepang betina, pakan standar puyuh Jepang, serbuk kunyit, vaksin ND2, mineral saquate, aquades, jangka sorong, kaca pembesar, kandang standar puyuh, dan dissecting set.

\section{c. Metode Penelitian}

\section{- Pembuatan Serbuk Kunyit}

Serbuk kunyit dibuat dari $8 \mathrm{~kg}$ rimpang basah yang berasal dari rimpang utama kunyit (Curcuma longa L.) yang telah diproses menjadi $1 \mathrm{~kg}$ serbuk kunyit kering. Pembuatan serbuk kunyit dilakukan di BALITRO Bogor. 
- Penimbangan Serbuk Kunyit

Serbuk kunyit ditimbang sesuai dengan dosis perlakuan yaitu $54 \mathrm{mg} /$ ekor/hari dan $108 \mathrm{mg} /$ ekor/hari. Penentuan dosis 54 didasari pada penelitian sebelumnya yaitu Saraswati et al., 2015, yaitu $54 \mathrm{mg} /$ ekor/hari adalah dosis paling optimal dalam memberikan pengaruh pada tingkat produksi telur puyuh Jepang. Penimbangan untuk perlakuan $54 \mathrm{mg} /$ ekor/hari dikalikan 3, karena akan diberikan pada satu kandang yang terdiri dari 3 ekor puyuh Jepang sehingga menjadi $162 \mathrm{mg} / \mathrm{kandang} /$ hari, sedangkan untuk dosis $108 \mathrm{mg} /$ ekor/hari ditimbang sebanyak 324 $\mathrm{mg} / \mathrm{kandang} / \mathrm{hari}$. Penentuan jumlah individu pada setiap kandang sebanyak 3 ekor puyuh Jepang adalah disebabkan karena penyesuaian terhadap sifat dasar puyuh Jepang yang hidup secara berkoloni (berkelompok).

\section{- Pencampuran serbuk kunyit pada pakan}

Serbuk kunyit pada masing-masing perlakuan dicampurkan dengan pakan standar puyuh sebanyak 30 g/kandang/hari. Air sebanyak 10 semprotan digunakan untuk mencampurkan serbuk kunyit dengan pakan yang sudah disediakan sebanyak $30 \mathrm{~g} / \mathrm{kandang} /$ hari, kemudian diaduk sampai tercampur rata. Pakan yang sudah dicampur, selanjutnya dikeringanginkan di atas kertas pada tempat yang tidak terkena sinar matahari secara langsung.

\section{- Pemberian serbuk kunyit}

Campuran pakan standar yang mengandung $30 \mathrm{~g}$ serbuk kunyit diberikan setiap pagi pukul 06.00 WIB pada setiap kandang sesuai dengan perlakuan. Serbuk kunyit diberikan sebelum masak kelamin mulai sejak umur 14 hari selama 30 hari.

\section{- Pengukuran parameter penelitian}

Pengukuran hierarki folikel dilakukan dengan terlebih dahulu menyembelih puyuh Jepang. Puyuh Jepang disembelih dengan memotong vena jugularis dan mengamati bagian organ reproduksi puyuh jepang untuk mendapatkan parameter pengukuran. Hierarki folikel puyuh Jepang dihitung berdasarkan jumlah hierarki yang matang 
(Saraswati et al., 2015b). Hierarki folikel yang matang ditandai dengan warna kuning.

- Rancangan percobaan

Rancangan percobaan yang digunakan adalah rancangan acak lengakap (RAL) dengan 3 perlakuan dan 5 ulangan. 45 ekor puyuh jepang dibagi ke dalam tiga kelompok, yaitu: puyuh Jepang tanpa diberikan serbuk kunyit atau kontrol, puyuh Jepang yang diberi serbuk kunyit 54 $\mathrm{mg}$ /ekor, dan puyuh Jepang yang diberikan serbuk kunyit 108 mg/ekor, masing-masing-masing ulangan berisi 3 ekor puyuh Jepang. Data dianalisis menggunakan analysis of variance (ANOVA) dan dilanjutkan uji Duncan dengan selang kepercayaan $95 \% \quad(\alpha=0,05)$. Analisa keseluruhan menggunakan perangkat lunak minitab 16 (Mattjik dan Sumertajaya 2006).

\section{d. Parameter Penelitian}

Parameter yang diamati adalah jumlah dan diameter hierarki folikel puyuh Jepang (Coturnix-coturnix japonica L.).

e. Anaslis Data

Semua data dianalisis menggunakan software SAS dan uji lanjut dengan LSD (Least Significant Difference) pada taraf kepercayaan 95\% ( $\alpha=0.05)$ (Mattjik dan Sumertajaya, 2006).

\section{HASIL DAN PEMBAHASAN}

Hasil analisis statistik jumlah hierarki folikel puyuh Jepang umur 120 hari yang diberikan suplemen serbuk kunyit sebelum masak kelamin memiliki hasil yang berbeda nyata $(\mathrm{P}<0.05)$, seperti yang terlihat pada Tabel 1.

Tabel 1.

Rataan jumlah hierarki folikel puyuh Jepang umur 120 hari.

\begin{tabular}{|l|c|c|c|}
\hline \multirow{2}{*}{ Variabel } & \multicolumn{3}{|c|}{ Kadar Serbuk Kunyit (mg/ekor/hari) } \\
\cline { 2 - 4 } & P0 & P1 & P2 \\
\hline $\begin{array}{l}\text { Jumlah hierarki folikel } \\
\text { (butir) }\end{array}$ & $\begin{array}{l}3.8^{\mathrm{b}} \\
\pm 0.91\end{array}$ & $4^{\mathrm{ab}} \pm 1.07$ & $4.6^{\mathrm{a}} \pm 0.37$ \\
\hline
\end{tabular}


Putra, S. H. J.

Keterangan: Angka yang diikuti dengan superskrip yang berbeda pada baris yang sama menunjukkan berbeda nyata $(\mathrm{P}<0,05)$. P0: tanpa serbuk kunyit (kontrol), P1: pemberian serbuk kunyit dengan kadar $54 \mathrm{mg} /$ ekor/hari, P2: pemberian serbuk kunyit dengan kadar $108 \mathrm{mg} /$ ekor/hari.

Pemberian suplemen serbuk kunyit berpengaruh nyata $(\mathrm{P}<0.05)$ meningkatkan jumlah hierarki folikel puyuh Jepang. Peningkatan dosis suplemen serbuk kunyit sampai dengan dosis $108 \mathrm{mg} /$ ekor/hari memberikan dampak terhadap peningkatan jumlah hierarki folikel (Gambar 1). Peningkatan jumlah hierarki folikel puyuh Jepang dimungkinkan adanya peningkatan distribusi vitelogenin dari hati ke ovarium. Optimalnya kondisi fisiologi puyuh Jepang yang ditandai dengan penurunan kadar kolesterol, trigliserida, lemak abdominal, dan lemak subkutan. Kadar lemak pada daerah abdominal dan subkutan terhitung rendah setelah diberikan suplemen serbuk kunyit sebelum matang kelamin (Putra $\mathrm{dkk}, 2015)$. Hal ini berdampak positif terhadap aktivitas metabolisme lipid di hati. Sintesis vitelogenin yang meningkat ditandai dengan meningkatnya jumlah hierarki folikel.

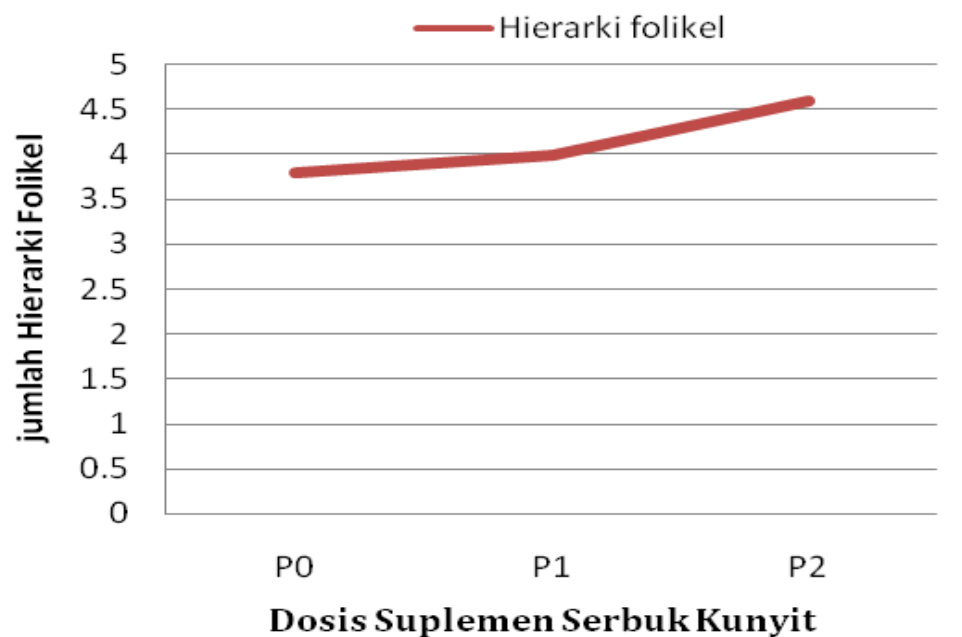

Gambar 1. Grafik peningkatan jumlah hierarki folikel Puyuh Jepang setelah pemberian suplemen serbuk kunyit sebelum matang kelamin. 
Hasil metabolisme lipid berupa vitelogenin di hati akan langsung didistribusikan ke seluruh jaringan. Salah satunya adalah distribusi vitelogenin dari hati ke ovarium untuk pembentukan hierarki folikel. Putra et al., (2015) menjelaskan bahwa terjadi penurunan kadar trigliserida di hati, serum dan daging puyuh Jepang setelah pemberian suplemen serbuk kunyit sebelum matang kelamin. Penurunan kadar kolesterol daging dan kuning telur puyuh Jepang (Putra dkk, 2016) dan kadar kolesterol hati puyuh Jepang (Putra dan Mansur, 2017) juga mengalami penurunan yang signifikan setelah pemberian suplemen serbuk kunyit sebelum matang kelamin. Lipid berupa trigliserida dan kolesterol yang ada dalam darah, hati dan daging disintesis di hati menjadi vitelogenin. Hal ini membuktikan bahwa kurkumin memberikan efek estrogenik untuk menginduksi hati agar meningkatkan sintesis vitelogenin. Terbukti dari banyaknya jumlah hierarki folikel puyuh Jepang yang terbentuk. Putra dkk, (2016) menambahkan bahwa kadar kolesterol tertinggi berada pada kolesterol kuning telur. Tingginya kadar kolesterol kuning telur disebabkan karena telur merupakan akhir dari distribusi vitelogenin yang tersusun oleh kolesterol dan trigliserida.

Semakin meningkat aktivitas sintesis vitelogenin, maka semakin banyak vitelogenin yang terdistribusi ke hierarki folikel (Levi et al., 2009). Hal ini mengindikasikan semakin banyak hierarki folikel yang matang. Terlihat dari jumlah hierarki folikel puyuh Jepang yang berkembang menunjukkan bahwa pemberian suplemen serbuk kunyit dapat meningkatkan jumlah hierarki folikel. Banyaknya hierarki folikel puyuh Jepang yang mengalami perkembangan ditandai dengan semakin besarnya ukuran hierarki folikel, seperti yang terdapat pada Tabel 2, serta adanya tumpukan vitelogenin pada hierarki folikel yang ditandai dengan warna kuning pada hierarki folikel tersebut. Semakin banyak folikel yang berkembang, maka dibutuhkan kadar kolesterol dan trigliserida yang lebih banyak sebagai bahan pembentuk kuning telur. 
Tabel 4.5.

Diameter masing-masing hierarki folikel puyuh Jepang umur 120 hari.

\begin{tabular}{|c|c|c|c|c|c|c|}
\hline \multirow{2}{*}{ Perlakuan } & \multirow{2}{*}{ Ulangan } & \multicolumn{5}{|c|}{ diameter hierarki folikel (cm) } \\
\cline { 3 - 7 } & & F1 & F2 & F3 & F4 & F5 \\
\hline P0 & 1 & 1.674 & 1.172 & 0.712 & 0.492 & - \\
\hline & 2 & 1.694 & 1.365 & 1.048 & 0.678 & - \\
\hline & 3 & 1.595 & 1.225 & 0.885 & - & - \\
\hline & 4 & 1.665 & 1.501 & 1.225 & 0.745 & - \\
\hline & 5 & 1.665 & 1.355 & 0.915 & 0.614 & - \\
\hline P1 & 1 & 1.735 & 1.336 & 1.016 & 0.768 & - \\
\hline & 2 & 1.598 & 1.355 & 0.885 & - & - \\
\hline & 3 & 1.755 & 1.418 & 1.025 & 0.678 & - \\
\hline & 4 & 1.696 & 1.265 & 1.085 & 1.665 & - \\
\hline & 5 & 1.915 & 1.674 & 1.226 & 0.735 & 0.524 \\
\hline \multirow{2}{*}{ Perlakuan } & Ulangan & \multicolumn{7}{c}{ diameter hierarki folikel (cm) } & \\
\cline { 3 - 8 } & & F1 & F2 & F3 & F4 & F5 \\
\hline P2 & 1 & 1.735 & 1.464 & 1.165 & 0.865 & - \\
\hline & 2 & 1.778 & 1.595 & 1.365 & 0.995 & 0.595 \\
\hline & 3 & 1.716 & 1.526 & 1.095 & 0.786 & 0.656 \\
\hline & 4 & 1.755 & 1.512 & 1.136 & 0.786 & 0.586 \\
\hline & 5 & 1.788 & 1.475 & 1.116 & 0.725 & - \\
\hline
\end{tabular}

Keterangan: P0: tanpa serbuk kunyit (kontrol), P1: pemberian serbuk kunyit dengan kadar $54 \mathrm{mg} /$ ekor/hari, P2: pemberian serbuk kunyit dengan kadar 108 mg/ekor/hari. F1, F2, F3, F4, dan F5 adalah hierarki folikel yang sudah matang yang dimulai dengan urutan dari yang terbesar ke yang terkecil. Sebagian besar hewan uji puyuh Jepang pada setiap perlakuan tidak memiliki hierarki folikel pada F5.

Kolesterol dan trigliserida akan terdistribusi ke banyak hierarki folikel. Hal ini menyebabkan setiap telur puyuh Jepang yang diberikan suplemen serbuk kunyit akan memiliki kadar kolesterol dan trigliserida yang rendah. Hasil ini juga didukung oleh penelitian sebelumnya bahwa semakin tinggi pemberian serbuk kunyit sampai dosis $54 \mathrm{mg} /$ ekor/hari sebelum masak 
kelamin dapat meningkatkan jumlah hierarki folikel puyuh Jepang (Saraswati, 2013b), dan penelitian Putra, dkk., (2016) yang menyatakan bahwa semakin tinggi suplemen serbuk kunyit yang diberikan hingga dosis $108 \mathrm{mg} /$ ekor/hari dapat menurunkan kadar kolesterol kuning telur puyuh Jepang. Pemberian suplemen serbuk kunyit juga dapat meningkatkan jumlah produksi telur, karena dapat memperpanjang masa bertelur.

\section{KESIMPULAN}

Pemberian suplemen serbuk kunyit yang dicampurkan pada pakan sebelum gonad puyuh Jepang siap produksi mampu meningkatkan jumlah hierarki folikel puyuh Jepang. Dosis optimal suplemen serbuk kunyit yang dapat diberikan pada pakan dalam meningkatkan hierarki folikel puyuh Jepang adalah 108 mg/ekor/hari.

\section{DAFTAR PUSTAKA}

Agustina, L. (2006). Penggunaan Ramuan Herbal Sebagai Feed Additive Untuk Meningkatkan Performans Broiler. Prosiding Lokakarya Nasional Inovasi Teknologi dalam Mendukung Usaha Ternak Unggas Berdaya Saing. Pusat Penelitian dan Pengembangan Peternakan. Bogor.

Chattopadhyay. I., Biswa. K., Bandyopadhyay. U and Banerjee. R. K. (2004). Tumeric and Curcumin: Biological Action and Medicinal Applications. Current Science 87(1): 44-53.

El-Sayyad. H. I., Abou-El-Naga. A. M., Gadallah. A. A., and Bakr. I. H. (2010). Protective Effects of Allium sativum Against Defects of Hypercholesterolemia on Pregnant Rats and Their Off Spring. International Journal of Clinical Experimental Medicine 3(2):152-163

Emadi. M., Kermanshahi. H and Maroufyan. E. (2007). Effect of Varying Levels of Tumeric Rhizome Powder on Some Blood Parameters of Broiler Cickens Fed Corn-Soyben 
Putra, S. H. J.

Meal Based Diets. International Journal of Poultry Science 6 (5): 345-348.

Handarini. R., Saleh. E. dan Togatorop. B., (2008). Produksi Burung Puyuh yang Diberi Ransum Dengan Penambahan Tepung Umbut Sawit Fermentasi. Agribisnis Peternakan 4 (3): 107.

Hardinsyah, Hadi. R. dan Victor. N. (2010). Kecukupan Energi, Protein, Lemak, dan Karbohidrat. Departemen Gizi Masyarakat. Fakultas Ekologi Manusia. Institut Pertanian Bogor. Bogor.

Levi. L., Pekarski. I., Gutman. E., Fortina. P., Hyslop. T., Biran. J., Levavi. B and Lubbzens E. (2009). Licensee Biomed Central Ltd.http://www.biomedcentral.com/1471-2164/10/141.

Listiyowati. E dan Roospitasari. K. (2007). Puyuh. Tata Laksana Budidaya Puyuh Secara Komersial. Penebar Swadaya: Jakarta.

Mattjik. A. A dan Sumertajaya. I. M. (2006). Perancangan Percobaan dengan Aflikasi SAS dan MINITAB. Ed ke-3. IPB Press: Bogor.

Peter. J. K. (2009). Lipid and Membran; Harper's Illustrated Biochemistry $2^{\text {th }}$ Edition. The McGraw-Hill Companies: United States of America. Hal. 236-237.

Puastuti. W. (2001). Pengaruh Pemberian Temulawak (Curcuma xanthorrhiza Roxb.) dan Minyak Kelapa dalam Ransum Terhadap Kadar Lemak dan Kolesterol Telur. Seminar Nasional Teknologi Peternakan dan Veteriner. 609-615.

Putra, S.H.J. dan Mansur, S. (2017). Pengaruh Pemberian Suplemen Serbuk Kunyit (Curcuma longa L.) terhadap Kadar Kolesterol Hati Puyuh Jepang (Coturnix coturnix japonica L.). Mangifera Edu. Vol. 11(1): 25-31. 
Putra, S.H.J., Saraswati, T.R., Isdadiyanto, S. (2015). Bobot Lemak Abdomen dan Lemak Subkutan Puyuh Jepang (Coturnix coturnix japonica) setelah pemberian serbuk kunyit (Curcuma longa). Prosiding Seminar Nasional II 2015. Magister Biologi, Fakultas Sains dan Matematika, Universitas Diponegoro. Semarang. No. 10.

Putra, S.H.J., Saraswati, T.R., Isdadiyanto, S. (2015). Profile Triglycerides Japanese Quail (Coturnix coturnix japonica) after Giving Turmeric (Curcuma longa) Powder. International Journal of Science and Engineering Vol. 8 (1): 65-68.

Putra, S.H.J., Saraswati, T.R., Isdadiyanto, S. (2016). Kadar kolesterol kuning telur dan daging puyuh jepang (Coturnix coturnix japonica) setelah pemberian suplemen serbuk kunyit (Curcuma longa). Buletin Anatomi dan Fisiologi, dh Sellula. Vol. 24 (1): 108-114.

Rahmad. D. dan Wiradimadja. R. (2011). Pendugaan Kadar Kolesterol Daging dan Telur Berdasarkan Kadar Kolesterol Darah pada Puyuh Jepang. Jurnal Ilmu Ternak 11 (1): 3538.

Respati. E., Hasanah. L., Wahyuningsih. S., Sehusman, Manurung. M., Supriyati. Y dan Rinawati. (2013). Pusat Data dan System Informasi Pertanian. Bulletin Konsumsi Pangan 4 (2): 1-56.

Saidin. M. (2000). Kandungan Kolesterol dalam Berbagai Bahan Makanan Hewani. Buletin Penelitian Kesehatan 27 (2): 224-230.

Salvante. K. G., Li. G., Walzem. R. L and Williams. T. D. (2007). Characterization of Very Low Density Lipoprotein Particle Diameter Dynamics in Relation to Egg Production in a Passerine Bird. The Journal of Experimental Biology 210: 1064-1074. 
Putra, S. H. J.

Saraswati. T.R. (2013) ${ }^{\text {a }}$. Optimization of Physiological Conditions Japanese Quail (Coturnix Coturnix Japonica) With Turmeric Powder Supplementation (Curcuma Longa). Bogor Agricultural University. DT - Veterinary Science (151).

http://repository.ipb.ac.id/handle/123456789/66834

Saraswati. T.R. (2013) ${ }^{\mathrm{b}}$. Determination of Age at the Decline Physiological Condition of the Japanese Quail's Liver. Disertasi Sekolah Pascasarjana Institute Pertanian Bogor. Hal. 18-28.

Yamashita. R, Oshima. A, Baba. Y.H, Wada. M, Shibuya. K. (2011). Endocrine Disttupting effect of Low Dose $17 \beta$ Estradiol $\left(E_{2}\right)$ on Japanese Quail Were Detected by Modified OneGeneration Reproduction Study. The Journal of Toxicological Science 36(1): 43-57.

Ravindran. P. N., Babu. K. N and Sivaraman. K. (2007). Tumeric. The Genus Curcuma. CRC Press London: New York. Hal. 375-376. 